\title{
Review Essay: Incorporating a Life-Course Perspective in the Development of Research and Public Policy Impacting Older Refugees
}

\author{
THRMIGA SATHIYAMOORTHY, Interdisciplinary Studies, York University \\ Corresponding author: Thrmiga Sathiyamoorthy \\ thrmiga@yorku.ca
}

\begin{abstract}
Older refugees are widely recognized as one of the most at-risk populations living with multiple intersecting barriers of political insecurity, financial insolvency, and poor health. Drawing upon secondary literature, this review essay builds upon a critique of multiculturalism to argue that the successful integration of older refugees is a two-way process. This process includes: 1) refugees making active attempts to embed themselves into Canadian society, and; 2) government facilitating conditions to help refugees integrate. The social integration of refugee elders is not a personal issue. It is a public problem that requires active government intervention via generous universal benefits. I use the life-course theoretical perspective to undertake an analysis of public policies and existing research to identify structural determinants of older refugees' integration.
\end{abstract}

Keywords: Older refugees; public policy; life course; social integration

\section{Introduction}

Older refugees are increasingly recognized as one of the most at-risk populations living with multiple intersecting barriers of political insecurity, financial insolvency, and poor health (United Nations High Commissioner's Programme, 1998; 2000). Drawing on secondary literature, this paper examines what is known about the conditions of forced migration of older refugees in Canada and the challenges in the country of asylum from a life-course perspective. Challenges faced by older refugees are unique to each individual's socio-historical context, but public policies play a critical role in improving their quality of life in the country of settlement (Edmonston, 2013). Many of the disparities in health and economic security between Canadianborn, immigrant, and refugee elders exist because of inequitable public policies (Raphael, 2014). Research has shown that the changing nature of social integration in Canadian society has 
increased the importance of human capital and adaptability. Further, the conditions of postmigration, such as radical severance with one's home country, loss of social and economic resources, and culture shock are particularly difficult for older refugees, who are often less flexible than their younger counterparts to changing social and political environments (Hugman, Bartmolomei \& Pittaway, 2004; Fiddian-Qasmiyeh, Loescher, Long \& Sigona, 2014).

A primary goal of this paper is to review the influence that existing research related to the integration of older refugees in host societies has had on public policies. Drawing from past social sciences and public health research, there are tendencies to homogenize the experiences of older refugees with younger cohorts (Coombes et al., 1999; Baker, 1983). In fact, there is an inherent failure to explore the intersection of migration trajectories, age, gender, arrival status and class. Considering the relationship between research and policy, generalized understandings of older refugees are likely to be matched with group-based interventions that are not specific to the diverse needs of older refugees. Accordingly, responses to older refugees' integration are often characterized by an increasing dependence on informal supports (e.g. the family unit) and fragmentation of community support (Bauman, 2000). Such simplistic interpretations overlook the larger context within which exclusion operates. Current approaches risk concealing trajectories of inequality, especially those related to age and migration, that may underpin exclusion, restrictions to participation in Canadian society, and poor access to health and social services. The problem with homogenizing all refugees' experiences is that older people may be blamed for failing to integrate into their communities without considering the unique barriers they face for integration. Thus, it is necessary to recognize the trajectories of social exclusion and how the integration experience varies across social locations in later life.

Fortunately, there is recognition among scholars of the need to develop and identify good 
practices to learn more about the impact of multiple intersecting vulnerable identities of older refugees and how these can be taken into account when devising services and policies. Informed by the perspective that public policies are critical to creating conditions for the integration of older refugees, we need to ensure life-course principles are incorporated in policies to accommodate the impact of the 'refugee experience' in later life. This paper's primary argument is methodological in nature, where the utility life course perspective in future policy, health and social services-based research is recommended to foster research that critically examines structural barriers to older refugees' limited integration.

\section{Unpacking the Use of Integration and Assimilation}

To understand the intended use of the terms of integration and assimilation, I draw on various critiques of multiculturalism (Arat-Koc, 2005; Bannerji, 2000; Mackey, 2002; McLaren, 1994). These theorists argue that multiculturalism promotes conformity to mainstream Canadian culture in the public domain and tolerates ethnic-specific cultures in the private domain (Bun, 2004). Hence, multiculturalism is a means to eventual assimilation via a one-way integration as opposed to an actual two-way integration. The Multiculturalism Act officially promotes the equal participation of all individuals and groups in Canadian society and seeks feedback to eliminate barriers to participation. Thus, two-way integration is an opportunity for different groups to interact, learn new values, and gain new membership groups. However, becoming a

full member of society means having the same access to work and educational opportunities as other citizens, as well as having a sense of belonging, acceptance, and inclusion in Canadian society (Alba \& Foner, 2015). Two-way integration has been difficult for many older refugees. Those who do not find themselves reflected in this process can feel alienated from society and 
therefore less attached. One-way integration does not respect minority group's integrity, values, beliefs, and ways of life. Multiculturalism therefore becomes a means in which to sustain the status quo as opposed to ensuring a more equitable society. For society to function its constituent parts need to be linked; therefore, two-way integration is vital.

\section{Theoretical Frameworks}

To understand the impact of public policies on various social institutions that contribute to economic and health equity for older refugees, a life-course perspective is useful. In fact, several scholars have used the life course perspective, with a focus on early-life, to accurately assess and to improve the well-being of older adults (Chapko et al., 2016; McDonald and Thomas, 2013; Kuh, 2007). Further, Raphael (2013) has pioneered an approach to utilize a lifecourse perspective to explain how public policies impact individuals over their life course. Raphael points out that countries with progressive public policies that support stronger benefits have lower poverty rates throughout an individual's life course. The life-course perspective acknowledges the accumulation, maintenance, and loss of human capital over the life course. It also includes the reconciliation of work and family (Raphael, 2014). Because the host country has no control over the type of policies implemented in a refugees' country of origin, there is a greater need to strengthen the economic and health security of older refugees in the country of asylum (i.e. the role of Canada as a host country). Forced migration is a dynamic phenomenon, where life experiences are shaped by time and socio-historical context. Earlier life experiences prior to settlement will dictate structural (e.g. socio-economic status, social support, family arrangement), behavioural (e.g. personality traits, coping methods) and psychosocial (e.g. critical life events, stress, psychological resources) determinants of health in old age (Raphael, 2014). However, an older refugee's life course can have positive turning points. These are described as 
sharp changes to life trajectories which are possible via effective public policies.

The government's contention over whether a particular problem is an individual or a societal concern often results in ineffective public policies (Langille, 2016). If the problem is a social one, the government has a responsibility to solve it, rather than imposing individual solutions. Because of Canada's deep-seated tradition of individualism, the public believes that many complex public problems, such as poor housing, low income, precarious work, and poverty, are private troubles (Myles, 2000; Mills, 2000). Since these issues are not considered public problems, government action is not deemed necessary and therefore they are often left to other sectors of society, such as the corporate sector, NGOs, and community centres (Estes, 2001). Leading scholars argue that the shift in responsibility away from the government is not acceptable because other sectors cannot effectively challenge and reform structural barriers such as gendered wage gaps (Languille, 2016; Estes, 2001). The corporate sector is ill-suited to promote citizens' wellbeing. They are interested in maximum profits and encourage pro-business policies at the cost of improving the provision of education, health care, employment and income, food, and housing (Languille, 2016). Further, NGOs and community organizations are band-aid solutions and are some of the first groups to lose public funding due to cost-saving measures during economic downturns (Raphael, 2014).

It is exactly during these difficult periods that proactive policies that facilitate the conditions necessary for wellbeing are most important. In fact, Estes (2001) argues that the root of "private troubles" for older refugees, such as status loss, low income, and social isolation is linked to limited state involvement in old age security. The current focus on individual interventions further exacerbates the depressed social status of marginalized older adults, such as first-generation immigrants. Current social policies fail to acknowledge that persistent inequality 
in old age as a result of inequitable social structures (Minkler \& Estes, 1999). Structural barriers related to immigrant status, employment, language acquisition, access to appropriate social and health care, and increased isolation directly contribute to the poor wellbeing of older refugees (Vissandjee et al., 2001; Thurston et al., 2006). To address these barriers, scholars argue that the influence of the corporate sector on the welfare state needs to be investigated further to understand the conditions and quality of life of older adults generally (Estes, 2001; Minkler \& Estes, 1999; Vissandjee et al., 2001; Kapilashrami, Hills \& Meer, 2015). The role of the welfare state and Canada's perception of welfare is outside the scope of this paper. However, to reinforce the goal of this review essay, future research will need to account for the magnitude of state involvement in public problems. Such analysis will determine how successful policies are in resolving in public problems, such as the integration of older refugees.

Further, public policies need to be developed with regard to the future. This includes rectifying the potential long-term and intergenerational effects of forced migration. The lifecourse perspective is useful to study the effects of social and structural factors of forced migration experienced across the life-course and among subsequent generations (Elder Jr., Johnson \& Crosnoe, 2003; Lynch \& Smith, 2005). The life-course perspective will advance research and policy-making on the effects of forced migration on older refugees by acknowledging (1) the long-term and dynamic effects of forced migration and (2) its intergenerational effects (Gelfand \& Barresi, 1987). The next section of this review will discuss the importance of documenting the integration of older refugees and will summarize existing efforts to do so. Because the asylum process in each nation is produced by different legal and social systems, this section will focus on Canadian examples.

\section{Why focus on older refugees?}


According to United Nations High Commissioner for Refugees (UNHCR), about three percent of all refugees were 60 years or older in 2011 (2012). However, Claudia Bolzman (1994) suggests that older refugees should not be represented only by a statistic. They should be described qualitatively with a "series of factors — such as when, for example, exile took place, at what age the person was exiled, and for how long” (Fiddian-Qasmiyeh, Loescher, Long \& Sigona, 2014). Such factors are important indistinguishing between those who were old when they became refugees and those who grew old as refugees. Despite limited knowledge on both sub-populations, more research exists on the latter group. In light of this inequity in data collection, this paper attempts to provide a balanced overview of both sub-populations.

Durst (2005) argues that studies of immigrants aggregate data on both immigrants and refugees together. Such representation neglects the differences within and between these groups: immigrants (family, economic status, etc.) and refugees (assisted, sponsored, or seeking asylum). In fact, the mode of refugees' arrival in Canada is important for analysis. Older refugees arrive in two primary ways: 1) by seeking asylum after arrival in Canada or; 2) by selection from abroad and sponsored by an individual or organization in Canada (e.g. individual, organization or government; Rousseau, Crépeau, Foxen \& Houle, 2002). Refugees in need of protection from gross human rights violations are often accepted on humanitarian grounds. Another neglected group are individuals who arrive in Canada under different legal statuses but who have refugeelike backgrounds (i.e. family class immigrants; Slewa-Younan, Santalucia, McDonald, \& Salem, 2016). They often are not formally recognized as refugees but have been living with refugee-like experiences. For the purpose of this paper, all individuals who arrived in Canada with a refugee status or refugee-like background will be considered refugees. Therefore, it is timely to document the unique experiences of older refugees particularly. 
Literature on refugee behaviour often disregards the unique experiences of older members of incoming groups. This is a significant gap in research because to understand the impact of the refugee experience in old age, the interactions between the 'normal' aging process and accelerated changes due to forced migration must be understood (Slewa-Younan, Santalucia, McDonald, \& Salem, 2016). The aging process is accelerated for older refugees because of the stresses associated with forced migration, which are further exacerbated by discriminatory and individualistic policies in the host country. And yet, research overwhelmingly focuses on younger refugees and families with children. The disproportionate representation in research between young and old refugees consequently informs policies that better assist younger refugees relative to their older counterparts. Consequently, issues faced by older refugees are considered general problems faced by immigrant or ethnic minority elders (Gelfand \& Barresi, 1987). There is an assumption that assimilation techniques can be generalized to all members of a group entering a new culture, without adequately accounting for generational differences. However, it has been well documented that the acculturation process often generates intense conflicts in intergenerational families (Slewa-Younan, Santalucia, McDonald, \& Salem, 2016). Because Canada is increasingly becoming a country of asylum for many older refugees (Durst, 2005), there is a need for critical policy development and service modifications to assist the elderly in successful integration. The usefulness of a life-course perspective in developing proactive public policies is demonstrated in the following section.

\section{Challenges Faced by Older Refugees - An Analysis from the Life-Course Perspective} In particular, research derived from the life-course perspective pays close attention to historical contexts that have produced differential social, political, and economic outcomes for older refugees. It also recognizes the possibility of long-term and intergenerational effects of 
forced migration. This section will review seven key principles, including time of life, sociohistorical context, interlinked lives, agency, latency effects of trauma, intra-variability of cohorts, and transitions and trajectories of the life-course perspective, as defined by Hutchison (2010). These principles will inform the multi-dimensional narratives of post-settlement for older refugees. This information may be valuable to researchers and policy-makers because the means of analyzing the specific needs of older refugees goes beyond being an older adult or refugee. Rather, it involves taking into account their experiences across the life course to understand their current reality. This section also summarizes existing research around these principles and points to how policy can respond to these research findings.

Timing of Lives - Experiences of forced migration vary based on age and historical period due to differential access to resources, and changing economic and social conditions during exile (Hutchison, 2010). In addition to available resources, laws in the country of origin and asylum determine who is allowed to move and consequently shape the particular ages and characteristics of migrant cohorts. Forced migration occurs at different ages with little opportunity for pre-planning. Here again, the effects of forced migration are felt more intensely by older refugees who perceive their residence in the country of asylum as permanent (Bolzman et al., 2008). The significance of the historical era also has long-term impacts on their social integration (Fiddian-Qasmiyeh, Loescher, Long \& Sigona, 2014). For example, public and political attitudes about Asian migrants have increasingly become more welcoming, whereas in the early 1900s, Asian migrants faced various forms of discrimination from the Chinese Head Tax (Wohl et al., 2013), to the internment of Japanese citizens (Miki, 2004), and even the refusal of some Sikh and Tamil boat arrivals (Bradimore \& Bauder, 2011). Accordingly, public policies reflect changes in public attitudes and have resulted in more supportive policies to facilitate 
better integration of migrants into Canadian society.

Given this history, research often documents the following areas: 1) the time of entry and 2) the progress of migrants through the process of settlement (Fiddian-Qasmiyeh, Loescher, Long \& Sigona, 2014). In the former case, characteristics of immigrants at the time of arrival such as age, sex, or country of origin are documented. Such characteristics are eagerly documented to identify the decline or improvement of certain characteristics across cohorts. For example, the rate of employment among recent immigrants is an important indicator of successful integration. Because immigration is closely tied to employment (Mata \& Pendakur, 1999), if successive migrant cohorts have declining educational levels, then labour force participation, occupational choices, individual income, and integration into Canadian society are negatively impacted. Thus, there is a preference for younger refugees with the capability to acquire the official language and adapt to the mainstream Canadian way of life (Bolzman, 1994). Older refugees are not "ideal immigrants" because they are not thought to contribute as much to Canada's economy as their younger counterparts and subsequently utilize more publicly funded services. Hence, this discrimination is reflected in immigration policies via the Super Visa program implemented in 2011 (Root, Gates-Gasse, Shields \& Bauder, 2014; Simich, Beiser, Stewart \& Mwakarimba, 2005; Ager \& Strang, 2008).

Socio-Historical Context - Forced migration has unique features that differentiate it from voluntary migration. First, it does not occur in a vacuum and is greatly influenced by social and economic conditions that enable migration from communities of origin. This must be followed by acceptance and integration in the country of asylum (Fiddian-Qasmiyeh, Loescher, Long \& Sigona, 2014). Because forced migration is often politically motivated, the decision to move affects not only the community of origin but also the community of asylum. The social, political 
and economic contexts of particular periods motivate social mobility while factors present during other periods act as barriers. For instance, during the $19^{\text {th }}$ and early $20^{\text {th }}$ century, many migrants from Europe were welcomed with few restrictions (Rousseau, Crépeau, Foxen \& Houle, 2002). However, during the same period, the exclusion of migrants from China and other racialized countries, people with disabilities, and many Jewish people, was practiced. While these divergent policies were racist, ableist, and anti-Semitic, they were also economically and politically motivated. The quotas on migration were first established in 1921 during a period of economic downturn. Accordingly, period-specific federal policies constricted the rights to and access to public benefits for some migrants based on their legal status (Marrow, 2012).

A recent example of period-specific policies is the change to the Super Visa program in January 2014, which made it more difficult to sponsor parents and grandparents (Canada Gazette, 2013). Changes include increasing the financial threshold by $30 \%$ above the previous necessary income to qualify to sponsor, increasing the period where the income requirement must be maintained from one to three years, and extending the sponsorship-undertaking period when the sponsor is financially responsible for the sponsored person) from ten to twenty years (. These combined changes meant only well-established Canadians would be able to reunite with their parents and grandparents. Although the Super Visa initiative was maintained, meaning the accepted visitor can stay up to two years in Canada, this is not an acceptable proxy for family reunification. Some immigrant families are already faced with unpredictable, precarious economic circumstances upon settlement and the current immigration policy shift is adding to their financial burden as supportive systems are lacking. These changes disproportionately impact racialized Canadians and women, who over-represent those living in poverty. These groups would benefit with the support of their parents and grandparents to integrate into 
Canadian society, particularly in gaining entry into the workforce.

Interlinked Lives - Older refugees transmit a wealth of accumulated knowledge and past experiences to inform family decisions and activities that impact their own lives as well as their families and ethnic communities (Hutchison, 2010). Forced migration disrupts families through the physical separation of family members. In fact, younger family members often leave their home country to find refuge abroad, while older adults often stay behind because of reduced mobility (Fiddian-Qasmiyeh, Loescher, Long \& Sigona, 2014; Slewa-Younan, Santalucia, McDonald, \& Salem, 2016). Yet, when possible, older refugees follow their adult children because they do not want to be alone in old age (Fiddian-Qasmiyeh, Loescher, Long \& Sigona, 2014). During this separation, family life is reframed. Family members develop transnational ties and established intergenerational support mechanisms begin to disintegrate, forcing families to negotiate new ways of coping. For resettled older refugees, the cultural respect linked to old age decreases, because they are seen as economically unviable and therefore dependent on younger family members (Gelfand \& Barresi, 1987). Higher status is often assigned to younger family members because they are able to speak the official languages more comfortably, are able to navigate social systems, and are financially more independent (Bolzman, Fibbi, Vial \& Guillon, 2001). Consequently, older refugees are sometimes trapped in a cycle of poverty and become dependent on their children for their livelihood (Minkler \& Estes, 1999). The loss of status, economic resources, and social capital, in addition to the experience of persecution, leaves older refugees in a distressed position. Accordingly, the UNHCR argues that older refugees' needs should not be dealt with in isolation, but rather in the context of family and community to ensure sustained support. Accordingly, public policies should address older refugees' needs in the context of family and community (United Nations High Commissioner's Programme, 1998; 
2000).

Agency - Regardless of older refugees' severe plight in exile, they are not passive recipients of assistance (Hutchison, 2010). Older refugees are often formal or informal leaders in their ethnic communities who offer guidance and advice in conflicting situations, and transmit cultural values and language skills to younger generations with hopes to preserve their traditions and ethnic identity. Therefore, older refugees make active contributions to the rearing of future generations. Therefore, policies need to identify older refugees as active members in their ethnic communities and ensure there are opportunities for older refugees' agency to be utilized.

However, three realities hinder older refugees' agency. These include: social disintegration, negative social selection, and chronic dependency (United Nations High Commissioner's Programme, 1998; 2000). These problems are often compounded. Social disintegration is the deterioration of social support in times of war or flight that result in the separation of families. Families make painful decisions about the abandonment of elders in order to survive and protect younger kin. Those who stay behind are the hardest hit because they have lost their former entitlements, their homes and other economic assets. Further, the erosion of support networks could, arguably, result in the deterioration of older adults' authority and negotiation abilities. Second, negative social selection occurs when the young, healthy and ablebodied depart, leaving behind the more vulnerable or marginalized members of the group, such as the disabled, elderly, and sick (United Nations High Commissioner's Programme, 1998; 2000; Slewa-Younan, Santalucia, McDonald, \& Salem, 2016). The plight of the elderly is particularly concerning because many countries are unlikely to provide them refuge because they are seen as dependents. Because chronic dependency is common in exile, older refugees become dependent on their family or the state (Estes, 2001; Gelfand \& Barresi, 1987). To support older refugees, 
policies must ensure universal access to public benefits, rights and entitlements. A comprehensive policy on the integration of elderly refugees should take into account both their needs and the contributions they make, and commensurate generously.

Latency Effects of Trauma - Exposures to acute and chronic stressors of forced migration may have lasting effects in old age. Refugees may encounter traumatic physical and psychological experiences (Castenda et al., 2015) that have lasting irreversible impacts on their physical and mental health (Negi \& Ganguly, 2011; Walter, Bourgois \& Loinaz, 2004). Furthermore, older refugees have limited power to change exposure to stressors such as chronic isolation in later life, which increases their risk for depression (Negi \& Ganguly, 2011). Also, as refugees grow older, traumatic memories may resurface (Slewa-Younan, Santalucia, McDonald, \& Salem, 2016; Fiddian-Qasmiyeh, Loescher, Long \& Sigona, 2014). Because of reduced interactions and a lack of meaningful work outside the home, many may remember their past experiences more vividly (Fiddian-Qasmiyeh, Loescher, Long \& Sigona, 2014). The reemergence of traumatic experiences is particularly powerful for those who have encountered them more recently; in these cases, such memories eclipse more recent experiences (Geland \& Barresi, 1987). For older refugees, regardless of when they experienced trauma, the refugee experience is carried through their life course and often accelerates their aging process (FiddianQasmiyeh, Loescher, Long \& Sigona, 2014). While older refugees are often fundamental strengths to their families (Johnson, 1998), their assistance can be undermined by past traumatic experiences that may have serious health implications as they age (Comley, 1998; Klimidis \& Minas, 1999). Public policies should account for the accumulated stress in later life and offer comprehensive care to prevent further deterioration of their mental health.

Intravariability of Cohorts - Older refugees, who often transition into immigrant seniors, 
continue to differ from Canadian-born seniors because of increased risks for chronic conditions and poor mental health (i.e. dementia, depression and delirium; Slewa-Younan, Santalucia, McDonald, \& Salem, 2016). The inevitable aging process of declining levels of functioning, frailty and memory loss further complicate later life for older refugees (Fiddian-Qasmiyeh, Loescher, Long \& Sigona, 2014). Moreover, older refugees tend to report worse self-rated health and encounter more functional limitations than Canadian-born seniors (Geland \& Barresi, 1987). Mental health needs are often prevalent in older refugees, but there is a lot of variability among cohorts. In fact, it has been concluded by the UNCHR that mental health needs are a consequence of the number of traumatic events experienced by a specific cohort rather than being a function of ageing (United Nations High Commissioner's Programme, 1998; 2000). Therefore, policies should account for both pre- and post-migration experiences in order to better understand the complexities of integration for older refugees and whether integration can become more successful over time with an increased length of residence in the receiving country.

Transitions and Trajectories - In light of the latent effects of acute and chronic stressors experienced by older refugees, future life transitions that are age-appropriate, such as retirement, need to happen smoothly in the country of asylum. Because older refugees have experienced several obstructions to a 'normal' life course, public policies in the country of asylum have a duty to enable a healthy recovery in later life with comprehensive public benefits and services. Transitions are life changes that mark the entry or exit of social roles and are culturally, socially, and historically defined (George, 1993). Non-normative changes are transitions that occur outside the socially defined timeframe and expectations such as forced migration. Non-normative transitions can often impact a life trajectory, defined as long-term patterns, due to its implications on marriage, employment, and other areas. (Martin et al., 2014). It has been argued that public 
policies in the country of asylum need to rectify life-course transitions in later life for older refugees to enable conditions and create opportunities for healthy aging as seen as appropriate by these refugees (Chenoweth \& Burdick, 2001). Policies should also target specific life-course stages for which older refugees are known to be at a disadvantage. To address the need for more research in this area, the next section will consider existing evidence around the major transitions of old age common to older refugees and highlight how current policies make transitions into future life stages difficult. Existing research has been helpful in promoting this knowledge, however, the adoption of life course principles in policy-making has been limited. To successfully bridge this gap between research and policy, we need to integrate additional factors such as local context, community and political preferences, and available resources to create an environment where research evidence is critically interpreted and appropriately applied.

\section{Life-course Transitions and Current Policy Limitations for Adoption}

Critical policy-making is necessary to identify the gaps in state-mediated care and governance. To illustrate these gaps, Edmonston (2013) identifies two life cycle stages pertinent to older refugees — older adult, and elderly—and seven social institutions - political/immigration, family, employment/ occupation, school/language, income, housing/mobility, and health. These categories are not meant to be exhaustive, but rather used for illustrative purposes. This crossclassification of life cycle stages and social institutions highlights examples of life-course transitions that warrant further attention by researchers and policy-makers. In the following paragraphs, each transition will be discussed in relation to older refugees in Canada.

Regardless of the method of entry, older refugees often have to wait before a permanent legal status is granted. The initial precarious legal status of older refugees limits their access to civil rights, health care, and employment opportunities (Torres \& Young, 2016). Through 
naturalization, older refugees gain access to social institutions, such as health care and employment, alike to Canadian-born and other first-generation seniors (Simich, Beiser, Stewart \& Mwakarimba, 2005). However, immigration policies sometimes function as a structural barrier for older refugees in accessing financial benefits. For instance, Old Age Security (OAS) benefits are exclusively offered to seniors who are 65 or older and who have resided in Canada for at least 10 years after the age of 18 (Shahidi, 2011). Further, older refugees are not eligible for Canada Pension Plan benefits if they have not contributed to it for at least 39 years (Myles, 2000). Another related concern is the expectation of families who sponsor their relatives to independently support their elders financially and provide basic necessities (Murphy, Zhang \& Dionne, 2012). Accordingly, older refugees sponsored will not be eligible for social assistance and can only receive OAS after 10 years of residence in Canada. These three realities are linked to the economic insecurity of older refugees, which impacts their integration into Canadian society.

Employment and income result in many disparities for older refugees. It has been reported that racial minorities and immigrants (which includes older refugees) often earn less and work in menial, manual labour positions compared to their native-born white counterparts (Block \& Galabuzi, 2011). Older refugees who arrived in Canada before the usual retirement age of 65 may not have received remuneration that is commensurate with their professional qualifications. The widespread reality of racial and gender discrimination, deprofessionalization, and the deskilling of older refugees has resulted in precarious working situations (Coloma \& Pino, 2016). Accordingly, the few older refugees who do work are unable to make substantial contributions to the Canada Pension Plan and are often forced to continue working after the usual age of retirement of 65 . In fact, Estes argues that the preretirement class of older refugees is a 
critical determinant of their post-retirement conditions (Estes, 2001). Therefore, settled refugees who are impoverished, retire impoverished. Increasingly, older refugees depend on their adult children for income. As a result, older refugees live in intergenerational households for economic and cultural reasons (Slewa-Younan, Santalucia, McDonald, \& Salem, 2016; Fiddian-Qasmiyeh, Loescher, Long \& Sigona, 2014). While there are cultural expectations of filial cohabitation, intergenerational households are necessities to financially sustain the family.

In addition, intergenerational households are common because of the mutual caretaking and assistance provided by adult children for their parents (older refugees) and in reciprocity, older refugees caring for their young grandchildren (Geland \& Barresi, 1987). This is problematic because older refugees now have additional barriers to accessing social and health services because of their domestic and caregiving duties (Simich, Beiser, Stewart \& Mwakarimba, 2005). Co-opted by a cultural expectation for filial cohabitation and financial dependency, older refugees often have to negotiate their time, money and transportation according to family needs.

Another concern with intergenerational homes is that, as ethnic families become more assimilated to Canadian lifestyles, the nature of familial support expectations change. For example, in some ethnic communities, there is a stronger pattern of filial obligation among middle-aged adult children to their aging parents than younger cohorts (Bolzman, Fibbi, Vial \& Guillon, 2001). Despite traditional values, some families, especially those in lower socioeconomic levels, have more difficulty in fulfilling such obligations. These differential expectations and realities can often lead to strain and conflict in intergenerational households, especially when younger adult children are upwardly mobile and less culturally dependent on their elders. There is also grave concern about caregiver burden (Braun, Takamura \& Mougeot, 
1996) as the needs of older refugees are quite complex and assistance from social services may be more appropriate and even necessary for the wellbeing of the intergenerational household (Simich, Beiser, Stewart \& Mwakarimba, 2005).

Family dynamics, financial need, and poor access to public social services may hinder older refugees' integration. Other factors that contribute to the poor integration of refugee elders are costs for participation, lack of transportation and poor mobility, language barriers, cultural incompatibility, and a lack of information about social services (Gelfand \& Barresi, 1987). These barriers often constrain older refugees' use of existing resources (Hossen \& Westhues, 2013; Jang \& Chiriboga, 2011). Public policies need to assist families with older refugees to make healthy aging a reality by enabling supportive conditions (Fiddian-Qasmiyeh, Loescher, Long \& Sigona, 2014).

Older refugees have reported experiencing a lower quality of life accompanied by poor physical and mental health compared to other Canadian elders. Scholars Bolleni and Siem coined the "exhausted migrant effect," which is a result of precarious work in the home and new country of residence (Bollini \& Siem, 1995). For older refugees, their health status may be more compromised due to collective violence and persecution that could impact their self-esteem and depression, contributing to greater physical and mental deterioration in old age. The reality for many older refugees is that the experience of forced migration remains dominant in their memories. As older refugees age, the trauma and its concomitant effects resurface and manifest in various forms, including mental (e.g. anxiety, neurosis, depression, and paranoia) and physical conditions (Slewa-Younan, Santalucia, McDonald, \& Salem, 2016). Scholars Davidson (1980) and Scott (1997) claim that refugees' past traumatizing experiences become accentuated with time and often require clinical intervention. However, for older refugees, their access to health 
and social services, as asylum seekers or even as individuals with a more permanent status, may be constrained by legal, financial, and cultural barriers. Therefore, policies need to recognize such barriers and intervene with sensitivity to account for each elder's past experience, their coping skills, the availability of familial support, and access to services. In order for this to be possible, researchers need to also ask themselves what narratives are missing and how can they can engage with communities that have been historically excluded in this kind of work.

\section{Role of Public Policies in the Integration of Older Refugees}

Generally, ethnic minority communities provide a lot of support to older refugees. These community supports often manifest as informal support groups and associations that allow newcomers to meet other locals of their ethnicity and learn more about settlement in Canada. While these self-help initiatives are strengthened through community financing and local members living in close proximity so that they can be of assistance to each other, their ability in helping older refugees is limited (Slewa-Younan, Santalucia, McDonald, \& Salem, 2016). Older refugees with membership in ethnic associations are often less influenced by the cultural norms of the host society. This also depends on the amount of contact the elder has with the ethnic group relative to the host society. Generally speaking, given the potential for language and cultural barriers, in addition to their preference to be in the care of family and friends, older refugees are less influenced by the wider society. The increasing separation between the elder and host society is problematic because when life-changing transitions require older refugees to interface with segments of the host society, there is more dependence on cultural brokers (Gelfand \& Barresi, 1987). This dependence has conveniently been placed on families, ethnic communities, and friends to negotiate on behalf of their elders. While cultural supports are important, public institutions such as the government should actively remove barriers for 
integration to allow older refugees to become more comfortable seeking support outside their family, friends, and ethnic associations.

The resettlement of older refugees needs to be followed with proactive policies and publicly funded community support to address the following concerns: (1) differential health risks (such as stress from new social environment, poor working conditions), (2) adequate resources to manage those risks (e.g. income maintenance to prevent poverty in old age), and (3) the utilization of health-promoting services (e.g. offer transportation to social and health services, educate elders about public benefits in their own language; Simich, Beiser, Stewart \& Mwakarimba, 2005; Slewa-Younan, Santalucia, McDonald, \& Salem, 2016; Fiddian-Qasmiyeh, Loescher, Long \& Sigona, 2014; Geland \& Barresi, 1987). Proactive policies and activities have the potential to create positive environments that improve quality of life (Hacker et al., 2011; Simich, Beiser, Stewart \& Mwakarimba, 2005; Ager \& Strang, 2008). Policies (effective or not) shape social, political, and economic conditions that influence the wellbeing of older refugees. Further, these policies have the potential for 'spillover' effects across various social institutions and life cycle stages that impact the individual and their family, across generations and ethnic communities (Hutchison, 2010). The economic and human capital accumulated by individuals and their social ties to families, friends, and local community prior to migration will impact how well older refugees integrate into the receiving society. Differential or limited integration of older refugees affects younger generations (i.e. adult children and grandchildren) because it increases caregiver stress and results in strained familial relations; Slewa-Younan, Santalucia, McDonald, \& Salem, 2016; Geland \& Barresi, 1987). Understanding the dynamic nature of older refugees' diverse social, economic, and political circumstances allows for policymakers and researchers to change the conditions that shape their integration. 
Public policies should strengthen the capacity of families and ethnic communities in addition to elderly-specific support (United Nations High Commissioner's Programme, 1998; 2000; Fiddian-Qasmiyeh, Loescher, Long \& Sigona, 2014). Targeted approaches are not effective because the needs of older refugees impact not only themselves, but also their families, community, and future generations. In Canada, the provision of universal supports and benefits to families with elders is minimal. This is particularly true for families with older refugees (Raphael, 2014; Estes, 2001). Existing research suggests that the integration of older refugees needs to occur on a universal basis and this approach is consistent with reducing social stratification (i.e. less division between citizens) and decommodifying the necessities for wellbeing, leading, for example, toless dependence on the immediate family. All of these universal entitlements will make incremental changes for all seniors, including older refugees. For example, financial security via universal entitlements will allow older refugees to be relieved from caregiving duties, utilize funds to access public transportation independently, and concomitantly increase access to health and social services. Further, universal benefits and entitlements allow for greater independence for seniors.

\section{Conclusions}

The life-course perspective, and its core principles, can advance future research and policy-making related to the social integration of older refugees. In particular, the life-course perspective underscores the importance of thinking about how exposure to trauma and forced migration affect individuals across their life-course and their future generations. The literature reviewed in this article shows how life-course transitions highlight the social and structural factors that create barriers for older refugees' integration. Social integration of refugee elders is not solely a private issue, but rather a public problem that requires active government 
intervention. The focus on structural factors is particularly important given that poor integration is reflective of anti-inclusive policies that position older refugees unfairly, while it advantages Canadian-born or other immigrants who have lived in Canada long enough to have adequate access to resources such as income, savings, a supportive social network, recognized educational capital, and housing.

In this review essay, structural determinants to older refugees' integration are discussed from two different standpoints: the life-course perspective and the public policy approach. In the above analysis of challenges faced by older refugees, the strengths of the life-course perspective are highlighted through a discussion of the timing of their lives, socio-historical context, interlinked lives, agency, latency effects of trauma, intra-variability of cohorts, and transitions and trajectories. Critical public policy-making is necessary to examining the realities of older refugees in their last two life stages. The incorporation of a life-course framework in policymaking ensures past life histories are accounted for in state interventions. Future research that ties the life course perspective to public policy research can provide further evidence to strengthen the case to support older refugees through universal benefits. As long as older refugees continue to reside in Canada, there will always be a need for research that documents the potential impact of old-age specific policies on refugees, their adult children, and community members. This paper makes an important contribution to existing research by highlighting the structural barriers that lead topoor integration of older refugees, and by showing how the life course perspective can reveal these barriers. The most effective way to challenge and reform the structural barriers to social integration lies in the re-identification of this 'private trouble' as a public problem. Through the re-identification of the problem, we can explore how the distinctive experiences of refugees can be taken into account when devising policies and practices for older 
people in particular.

\section{References}

Ager, A., \& Strang, A. (2008). Understanding integration: A conceptual framework. Journal of Refugee Studies, 21(2), 166-191.

Alba, R., \& Foner, N. (2015). Strangers no more: Immigration and the challenges of integration in North America and Western Europe. Princeton University Press.

Arat-Koc, S. (2005). The disciplinary boundaries of Canadian identity after September 11:

Civilizational identity, multiculturalism, and the challenge of anti-imperialist feminism. Social Justice, 32(4 (102), 32-49.

Bannerji, H. (2000). The dark side of the nation: Essays on multiculturalism, nationalism and gender. Canadian Scholars' Press.

Block, S., \& Galabuzi, G. E. (2011). Canada's colour coded labour market: The gap for racialized workers. Canadian Centre for Policy Alternatives/Centre canadien de politiques alternatives.

Bollini, P., and Siem, H. (1995) 'No Real Progress Towards Equity: Health of Migrants and Ethnic Minorities on the Eve of the Year 2000'. Social Science and Medicine 41: 819-28.

Bolzman, C. (1994) 'Stages and Modes of Incorporation of Exiles in Switzerland: The Example of Chilean Refugees'. Innovation 7(3): 321-33.

Bolzman, C. (1996) Sociologie de l'exil. Une approche dynamique. L'exemple des réfugiés chiliens en Suisse. Zurich: Seismo.

Bolzman, C., Fibbi, R., Vial, M., \& Guillon, M. (2001). La famille: une source de légitimité pour les immigrés après la retraite? Le cas des Espagnols et des Italiens en Suisse. Revue européenne des migrations internationales, 17(1), 55-78. 
Bolzman, C., Hirsch-Durret, E., Anderfuhren, S., and Vuille, M. (2008) 'Migration of Parents under Family Reunification Policies: A National Approach to a Transnational Problem. The Case of Switzerland'. Retraite et société, 93-121.

Bradimore, A., \& Bauder, H. (2011). Mystery ships and risky boat people: Tamil refugee migration in the newsprint media. Canadian Journal of Communication, 36(4), 637.

Braun, K. L., Takamura, J. C., \& Mougeot, T. (1996). Perceptions of dementia, caregiving, and help-seeking among recent Vietnamese immigrants. Journal of Cross-Cultural Gerontology, 11(3), 213-228.

Castañeda, H., Holmes, S. M., Madrigal, D. S., Young, M. E. D., Beyeler, N., \& Quesada, J. (2015). Immigration as a social determinant of health. Annual review of public health, 36, 375-392.

Chapko, D., Staff, R. T., McNeil, C. J., Whalley, L. J., Black, C., \& Murray, A. D. (2016). Latelife deficits in cognitive, physical and emotional functions, childhood intelligence and occupational profile: a life-course examination of the Aberdeen 1936 Birth Cohort (ABC1936). Age and ageing, 45(4), 486-493.

Chenoweth, J., \& Burdick, L. (2001). The path to integration: meeting the special needs of refugee elders in resettlement. Refuge: Canada's Journal on Refugees, 20(1).

Coloma, R. S., \& Pino, F. L. (2016). " There's Hardly Anything Left": Poverty and the Economic Insecurity of Elderly Filipinos in Toronto. Canadian Ethnic Studies, 48(2), 71-97.

Comley, M. (1998). Counselling and therapy with older refugees. Journal of Social Work Practice, 12(2), 181-187.

Davidson, S. (1980) 'The Clinical Effects of Massive Psychic Trauma in Families of Holocaust Survivors'. Journal of Marital and Family Therapy 6: 9-21. 
Durst, D. (2005). Aging amongst immigrants in Canada: population drift. Canadian Studies in Population, 32(2), 257-270.

Edmonston, B. (2013). Lifecourse perspectives on immigration. Canadian Studies in Population, 40(1-2), 1-8.

Elder Jr, G. H., Johnson, M. K., \& Crosnoe, R. (2003). The emergence and development of life course theory. In Handbook of the life course (pp. 3-19). Springer US.

Elder, G. H. (1998). Jr. 1985.". Perspectives on the Life Course." In Glen H. Elder Jr.(ed.), Lfe Course Dynamics. Ithaca, NY: Cornell University Press.

Estes, C. L. (2001). Social policy and aging: A critical perspective. Sage.

Gee, G. C., Walsemann, K. M., \& Brondolo, E. (2012). A life course perspective on how racism may be related to health inequities. American Journal of Public Health, 102(5), 967-974.

Gelfand, D. E., \& Barresi, C. M. (1987). Ethnic dimensions of aging. Springer Pub. Co..

George, L. K. (1993). Sociological perspectives on life transitions. Annual review of sociology, 353-373.

Hacker, K., Chu, J., Leung, C., Marra, R., Pirie, A., Brahimi, M., ... \& Marlin, R. P. (2011). The impact of immigration and customs enforcement on immigrant health: perceptions of immigrants in Everett, Massachusetts, USA. Social science \& medicine, 73(4), 586-594.

Hossen, A., \& Westhues, A. (2013). Bangladeshi elderly immigrants in Southern Ontario: Perspective on family roles and intergenerational relations. Journal of International Social Issues, 2(1), 1-15.

Hugman, R., Bartolomei, L., \& Pittaway, E. (2004). It is part of your life until you die: older refugees in Australia. Australasian Journal on Ageing, 23(3), 147-149.

Hutchison, E. D. (2010). A life course perspective. Dimensions of human behavior: The 
changing life course, 1-38.

Jang, Y., \& Chiriboga, D. A. (2011). Social Activity and Depressive Symptoms in Korean American Older Adults the Conditioning Role of Acculturation. Journal of Aging and Health, 23(5), 767-781.

Johnson, P. J. (1998). Performance of Household Tasks by Vietnamese and Laotian Refugees Tradition and Change. Journal of Family issues, 19(3), 245-273.

Kapilashrami, A., Hill, S., \& Meer, N. (2015). What can health inequalities researchers learn from an intersectionality perspective \& quest; Understanding social dynamics with an inter-categorical approach \& quest. Social Theory \& Health, 288-307.

Klimidis, S., \& Minas, H. (1999). Mental illness in elderly immigrants: a need to focus on the issues. Migration Action, 21(1), 23-27.

Kuh, D. (2007). A life course approach to healthy aging, frailty, and capability. The Journals of Gerontology Series A: Biological Sciences and Medical Sciences, 62(7), 717-721.

Langille, D. (2016). Follow the money: how business and politics define our health. Social determinants of health: Canadian Perspectives, 470.

Lara, M., Gamboa, C., Kahramanian, M. I., Morales, L. S., \& Hayes Bautista, D. E. (2005). Acculturation and Latino health in the United States: a review of the literature and its sociopolitical context. Annu. Rev. Public Health, 26, 367-397.

Lynch, J., \& Smith, G. D. (2005). A life course approach to chronic disease epidemiology. Annu. Rev. Public Health, 26, 1-35.

Mackey, E. (2002). Managing the house of difference: Official multiculturalism. The house of difference: Cultural politics and national identity in Canada, 50-70.

Marrow, H. B. (2012). Deserving to a point: unauthorized immigrants in San Francisco's 
universal access healthcare model. Social Science \& Medicine, 74(6), 846-854.

Martin, M. J., Blozis, S. A., Boeninger, D. K., Masarik, A. S., \& Conger, R. D. (2014). The timing of entry into adult roles and changes in trajectories of problem behaviors during the transition to adulthood. Developmental psychology, 50(11), 2473.

Massey, D. S., Alarcón, R., Durand, J., \& Gonzalez, H. (1990). Return to Aztlan: The social process of international migration from Western Mexico (Vol. 1). Univ of California Press.

Mata, F., \& Pendakur, R. (1999). Immigration, labor force integration and the pursuit of selfemployment. International Migration Review, 378-402.

McDonald, L., \& Thomas, C. (2013). Elder abuse through a life course lens. International psychogeriatrics, 25(8), 1235-1243.

McLaren, P. (2018). Revolutionary multiculturalism: Pedagogies of dissent for the new millennium. Routledge.

Miki, R. (2004). Redress: Inside the Japanese Canadian call for justice. Raincoast books.

Mills, C. W. (2000). The sociological imagination. Oxford University Press.

Minkler, M., \& Estes, C. L. (1999). Critical gerontology: Perspectives from political and moral economy.

Murphy, B. B., Zhang, X., \& Dionne, C. (2012). Low income in Canada: A multi-line and multiindex perspective. Ottawa: Statistics Canada.

Myles, J. (2000). The maturation of Canada's retirement income system: Income levels, income inequality and low income among older persons.Canadian Journal on Aging/La Revue Canadienne Du Vieillissement, 19(03), 287-316.

Negi, N. S., \& Ganguly, S. (2011). Development Projects vs. Internally Displaced Populations in 
India: A Literature Based Appraisal. Series on Environmental Degradation and Migration, 1-19.

Ng, E., Pottie, K., \& Spitzer, D. (2011). Official language proficiency and self-reported health among immigrants to Canada. Health Reports, 22(4), A1.

Raphael, D. (2013). Adolescence as a gateway to adult health outcomes. Maturitas, 75(2), 137141.

Raphael, D. (2014). Social determinants of children's health in Canada: Analysis and implications. International Journal of Child, Youth and Family Studies, 5(2), 220-239.

Regulations Amending the Immigration and Refugee Protection Regulations (2013, May 18). In Canada Gazette. Retrieved from http://www.gazette.gc.ca/rp-pr/p1/2013/2013-0518/html/reg2-eng.html

Root, J., Gates-Gasse, E., Shields, J., \& Bauder, H. (2014). Discounting immigrant families: Neoliberalism and the framing of Canadian immigration policy change. Ryerson Centre for Immigration \& Settlement (RCIS) Working Paper No, 7.

Rousseau, C., Crépeau, F., Foxen, P., \& Houle, F. (2002). The complexity of determining refugeehood: a multidisciplinary analysis of the decision- making process of the Canadian immigration and refugee board. Journal of refugee studies, 15(1), 43-70.

Scott, H. (1997) 'Ageing in Multicultural Europe: Making the Challenge—Setting the Agenda'. Paper presented for the Age Concern Scotland Scottish European Symposium for the European Year of Older People \& Solidarity between Generations, 15-16 December. Shahidi, F. V. (2011). Community-based Perspectives on the Political Economy of Immigrant Health: A Qualitative Study. Wellesley Institute.

Simich, L., Beiser, M., Stewart, M., \& Mwakarimba, E. (2005). Providing social support for 
immigrants and refugees in Canada: Challenges and directions. Journal of Immigrant and Minority Health, 7(4), 259-268.

Slewa-Younan, S., Santalucia, Y., McDonald, R., \& Salem, M. (2016). Enhancing the lives of older refugees: an evaluation of a training resource. International journal of mental health systems, 10(1), 1.

Thurston, W.E., Meadows, L., Este, D., \& Eisener, A. (2006). The interplay of gender, migration, socioeconomics, and health. PMC Working Paper, Prairie Centre of Excellence for Research on Immigration and Integration.

Torres, J. M., \& Young, M. E. D. (2016). A life-course perspective on legal status stratification and health. SSM-Population Health, 2, 141-148.

UNHCR (2012) Statistical Yearbook 2011. Geneva: UNHCR.

United Nations High Commissioner's Programme. (1998, August 14). The Situation of Older Refugees. Refugee Survey Quarterly, 17(4), 111-118.

United Nations High Commissioner's Programme. (2000, February 7). Older Refugees Looking Beyond the International Year of Older Persons. Refugee Survey Quarterly, 19(4), 231238.

Vissandjée, B., Weinfeld, M., Dupéré, S., \& Abdool, S. (2001). Sex, gender, ethnicity, and access to health care services: Research and policy challenges for immigrant women in Canada. Journal of International Migration and Integration, 2(1), 55-75.

Walter, N., Bourgois, P., \& Loinaz, H. M. (2004). Masculinity and undocumented labor migration: injured Latino day laborers in San Francisco. Social Science \& Medicine, 59(6), 1159-1168.

Wohl, M. J., Matheson, K., Branscombe, N. R., \& Anisman, H. (2013). Victim and perpetrator 
groups' responses to the Canadian government's apology for the head tax on Chinese immigrants and the moderating influence of collective guilt. Political Psychology, 34(5), 713-729. 